\title{
Hubungan Tingkat Kecemasan peserta dan Frekuensi Keikutsertaan Uji Kompetensi dengan Hasil Uji Kompetensi Bidan Nasional (UKBI) di Sulawesi Selatan Periode Juli-September 2020
}

\author{
Ferawati Taherong ${ }^{1,}$ Anieq Mumthi'ah Alkautzar ${ }^{2}$ \\ ${ }^{1,2}$ Fakultas Kedokteran dan Ilmu Kesehatan, \\ Email :ferawati.taherong@uin-alauddin.ac.id ${ }^{1}$, Anieq.mumthiah@uin-alauddin.ac.id ${ }^{2}$
}

\begin{abstract}
ABSTRAK
Latar belakang: Tingkat kelulusan uji kompetensi merupakan salah satu paramater untuk menilai tingkat efisiensi dan efektifitas proses belajar mengajar suatu institusi pendidikan. Pencapaian kelulusan uji kompetensi dipengaruhi oleh beberapa faktor baik internal maupun eksternal. Faktor internal yang sangat signifikan mempengaruhi hasil uji komptensi lulusan yaitu intelegensi, kondisi psikis (kecemasan), kondisi fisik, kesiapan ujian dan prestasi belajar.

Tujuan : penelitian ini mengetahui hubungan tingkat kecemasan dan frekuensi keikutsertaan peserta dengan hasil uji kompetensi bidan Indonesia.

Metode : Jenis penelitian survey analitik dengan pendekatan cross sectional study menggunakan teknik penarikan snowball sampling dengan jumlah sampel 192 responden.

Hasil : Ada hubungan yang signifikan antara tingkat kecemasan dengan hasil uji kompetensi dengan nilai $\mathrm{P}$ $=0,000(<$ nilai $\alpha)$, ada hubungan yang signifikan antara frekuensi keikutsertaan peserta dengan hasil uji kompetensi dengan nilai $\mathrm{P}=0,000((<$ nilai $\alpha)$. Semakin tinggi tingkat kecemasan dan semakin sering mengikuti uji kompetensi maka semakin besar tingkat kegagalan uji kompetensi lulusan. Perlu penelitian lebih lanjut bagaimana perbandingan tingkat kecemasan antara firstaker dan retaker mengahdapi Uji Kompetensi Bidan Indonesia.
\end{abstract}

Kata Kunci :Uji Kompetensi, Kecemasan

\begin{abstract}
Background: The passing rate of the competency test is one of the parameters to assess the level of efficiency and effectiveness of the teaching and learning process of an educational institution. The achievement of passing the competency test is influenced by several factors, both internal and external. Internal factors that significantly affect the results of the competency test of graduates are intelligence, psychological condition (anxiety), physical condition, test readiness and learning achievement.

Purpose: this study was to determine the relationship between the level of anxiety and the frequency of participant participation with the results of the Indonesian midwife competency test.

Method: This type of analytic survey research with a cross sectional study approach using the snowball sampling technique with a sample size of 192 respondents.

Results: There is a significant relationship between the level of anxiety and the results of the competency test with a value of $\mathrm{P}=0.000$ ( $<\alpha$ value), there is a significant relationship between the frequency of participant participation and the results of the competency test with a value of $\mathrm{P}=0.000$ ( $<\alpha$ value). The higher the level of anxiety and the more often you take the competency test, the greater the failure rate of the graduate competency test. Further research is needed on how to compare the level of anxiety between the firstaker and the retaker against the Indonesian Midwife Competency Test.
\end{abstract}

Keyword : Competency Test, Anxiety

PENDAHULUAN

Survey Demografi Kesehatan

Angka Kematian Ibu (AKI) berdasarkan

Indonesia (SDKI) menunjukkan bahwa

prosedur estimasi langsung diperkirakan

Volume 8 Nomor 2. Januari- Juni 2021 
sebesar 359 kematian maternal per 100.000 kelahiran hidup untuk periode 2008-2012. $\mathrm{Hal}$ ini menggambarkan peningkatan AKI dibandingkan periode 1994-2007 sebesar 228/ 100.000 kelahiran hidup. Sedangkan Angka Kematian Bayi (AKB) tahun 2012 sebesar 32 kematian per 1000 kelahiran hidup. ${ }^{(1,2)}$

Bidan adalah salah satu sumber daya manusia yang memiliki peran dalam menurunkan AKI dan AKB. AKI dan AKB dapat diturunkan melalui program pelaksanaan Kesehatan Ibu dan anak (KIA). Salah satu prinisip pengolalaan KIA adalah meningkatkan deteksi dini faktor risiko dan komplikasi kebidanan. Pengolalaan KIA membutuhkanbidan yang kompeten yang dapat dicapai melalui Uji Komptensi Bidan Indonesia (UKBI). ${ }^{(3)}$

Pelaksanaan UKBI dilaksanakan dengan tujuan untuk menyamakan standar mutu lulusan pada setiap institusi pendidikan kebidanan. Harapan setiap institusi pendidikan kebidanan adalah seluruh Lulusan lulus dalam menghadapi ujian kompetensi, namum dibeberapa institusi pendidikan pada kenyataannya tidak seperti apa yang diharapkan. Jumlah kelulusan ujian kompetensi tidak merata di seluruh Indonesia, ada yang jumlah kelulusannya 90-100\% dan nada yang jumlah kelulusannya hanya mencapai $10-30 \%$ pada setiap periode ujian kompetensi. Bagi Lulusan ujian kompetensi merupakan suatu tantangan yang harus dihadapi karena pada saat ini syarat untuk melamar pekerjaan bagi tenaga kesehatan adalah harus memiliki STR (Surat Tanda Registrasi). STR diperoleh apabila seorang mahasiswa dinyatakan lulusan (kompeten) pada pelaksanaan Uji Kompetensi. ${ }^{(4)}$
Uji kompetensi bidan adalah upaya pemerintah yang di dukung oleh organisasi terkait seperti IBI dan AIPKIND yang berdasar pada Peraturan Bersama antara Menteri Pendidikan dan Kebudayaan dan Menteri Kesehatan No. 3/VII/PB/2004 dan 52/2014 tahun 2014 tentang Penyelenggaraan Uji Kompetensi Mahasiswa Program Diploma III Kebidanan, Diploma III Keperawatan dan Profesi Ners. Tujuan uji kompetensi bidan adalah sebagai exit exam yang menjamin lulusan pendidikan tinggi kesehatan yang kompeten dan terstandar secara nasional dengan menguji pengetahuan dan keterampilan sebagai dasar dalam menjalankan profesionalisme dalam pelayanan. Uji Kompetensi tersebut melibatkan suatu proses untuk mengukur pengetahuan, keterampilan dan sikap tenaga kesehatan sesuai dengan standar profesi atau dalam arti lain uji kompetensi diharapkan menjadi media untuk meningkatkan kualitas tenaga kesehatan secara berkala. (14)

Daftar peserta uji kompetensi bidan dari periode 2017 sampai periode 2018 mengalami penurunan adalah sebagai berikut 33.792 peserta pada periode IX/2017, 19.957 periode $\mathrm{X} / 2018$ dan 13.146 peserta pada periode XI/2018. Tingkat kelulusan rata-rata periode masih rendah yaitu $55 \%$ tingkat kelulusan dan tingkat kelulusan rendah sangat terlihat pada periode uji kompetensi bidan saat retaker ikut sebagai peserta ujian yaitu periode VIII/2017 adalah 22,89 \% dan periode X/2018 adalah $27,95 \%$. (6)

Tingkat kelulusan uji kompetensi merupakan salah satu paramater untuk menilai tingkat efisiensi dan efektifitas proses belajar mengajar suatu institusi 
pendidikan. Pencapaian kelulusan uji kompetensi dipengaruhi oleh beberapa faktor baik internal maupun eksternal. Faktor internal yang sangat signifikan mempengaruhi hasil uji komptensi lulusan yaitu intelegensi, kondisi psikis (kecemasan), kondisi fisik, kesiapan ujian dan prestasi belajar. ${ }^{(\mathbf{5 , 6})}$

Kesiapan mengikuti ujian kompetensi dapat menimbulkan kecemasan, ditambah rendahnya presentase kelulusan pada UKBI dapat membuat lulusan menjadi kurang semangat. Apabila lulusan tidak dapat menyesuaikan kondisi terhadap masalah tersebut akan merasa cemas dan tidak berdaya. Hal ini dikarenakan pernah tidak lulus pada kesempatan sebelumnya, kurangnya persiapan, prestasi akademik yang rendah serta masalah kesehatan merupakan dampak dari faktor cemas dalam menghadapi UKBI. (7)

Kecemasan merupakan sifat ketakutan yang tidak pasti, berhubungan dengan perasaan raguragu atau tidak berdaya. Perasaan kecemasan begitu umum dirasakan oleh masyarakat, termasuk Lulusan. Kecemasan melibatkan respon tubuh, persepsidiri, dan hubungan dengan orang lain. Menurut Townsend, tahun 2005, kecemasan akan menjadi masalah ketika individu tidak dapat mencegah peningkatan kecemasan tersebut sementara Goff, tahun 2011 mengatakan bahwa kecemasan tingkat tinggi pada Lulusan keperawatan dapat mempengaruhi memori, konsentrasi, dan kemampuan pemecahan masalah, dan dapat menyebabkan belajar menurun, dan kinerja akademik menurun. Oleh karena itu tingkat stress tinggi dapat memiliki dampak buruk dalam menghadapi uji kompetensi. ${ }^{(7)}$

Maka dari itu perlu dilakukan penelitian dengan tujuan untuk mengetahui hubungan Tingkat Kecemasan Peserta dan Frekuensi Keikutsertaan dengan Hasil Uji Komptensi Bidan.

\section{METODE}

Jenis penelitian ini adalah penelitian kuantitatif dengan pendekatan analitik observasional menggunakan studi cross sectional. Data dikumpulkan melalui kuesioner online yang didistribusikan pada peserta ukom Lulusan kebidanan di Sulawesi-selatan. Teknik pengambilan sampel menggunakan snowball sampling yaitu suatu teknik yang multitahapan, didasarkan pada analogi bola salju, yang dimulai dengan bola salju yang kecil kemudian membesar secara bertahap karena ada penambahan salju ketika digulingkan dalam hamparan salju (12). Data di analisis secara univariate untuk melihat distribusi frekuensi karakteristik responden. Selain itu, juga untuk melihat hubungan tingkat kecemasan dan frekuensi keikutsertaan peserta dengan hasil uji kompensi bidan indonesia dilakukan analisis bivariate menggunakan uji fisher

\section{HASIL}


AnalisisUnivariat

Tabel 1. Distribusi Frekuensi Usia Lulusan Kebidanan Saat Mengikuti Ujian Kompetensidi Sulawesi Selatan Tahun 2020

\begin{tabular}{ccc}
\hline Usia & Frekuensi & $(\%)$ \\
\hline$\geq 25$ Tahun & 69 & 35,9 \\
$<25$ Tahun & 123 & 64,1 \\
\hline
\end{tabular}

Berdasarkan tabel 1. Dapat pada tahun 2020 berusia $<25$ tahun yaitu diketahui bahwa mayoritas peserta Ukom sebanyak 123 responden atau sebesar Lulusan Kebidanan di Sulawesi-selatan $\quad 64,1 \%$ dari total responden yang diteliti.

Tabel 2. Distribusi Frekuensi Tingkat Kecemasan Sebelum Mengikuti Ujian Kompetensi Pada Lulusan Kebidanan di Sulawesi Selatan Periode Juli-September Tahun 2020

\begin{tabular}{ccc}
\hline Tingkat Kecemasan & Frekuensi & $(\%)$ \\
\hline Tinggi & 23 & 12 \\
Rendah & 169 & 88 \\
\hline
\end{tabular}

Berdasarkan table 2. Dapat memiliki tingkat kecemasan yang rendah diketahui bahwa mayoritas peserta Ukom yaitu sebanyak 169 responden atau sebesar Lulusan Kebidanan di Sulawesi Selatan $88 \%$ dari total responden yang diteliti.

Periode Juli-September Tahun 2020

Tabel 3. Distribusi Frekuensi Keikutsertaan Ujian Kompetensi Pada Lulusan Kebidanan di Sulawesi Selatan Periode Juli-September Tahun 2020

\begin{tabular}{ccc}
\hline Fekuensi Keikutsertaan UKOM & Frekuensi & $(\%)$ \\
\hline First Taker & 66 & 34,4 \\
Re Taker & 126 & 65,6 \\
\hline
\end{tabular}

Berdasarkan table 3. Dapat pada tahun 2020 merupakan re taker yaitu diketahui bahwa mayoritas peserta Ukom sebanyak 126 responden atau sebesar lulusan Kebidanan di Sulawesi-selatan $\quad 65,6 \%$ dari total responden yang diteliti.

Tabel 4. Distribusi Frekuensi Hasil Ujian Kompetensi Lulusan Kebidanan di Sulawesi Selatan Periode Juli-September Tahun 2020

\begin{tabular}{ccc}
\hline Hasil UKOM & Frekuensi & $(\%)$ \\
\hline Kompeten & 58 & 30,2 \\
Tidak Kompeten & 134 & 69,8 \\
\hline
\end{tabular}

Berdasarkan table 4. Dapat kompeten yaitu sebanyak 134 responden diketahui bahwa mayoritas peserta Ukom atau sebesar $69,8 \%$ dari total responden Lulusan Kebidanan di Sulawesi-selatan yang diteliti.

pada tahun 2020 memiliki hasil yang tidak 
Analisis Bivariat

Tabel 5. Hubungan Tingkat Kecemasan dengan Hasil Ujian Kompetensi Pada Alumni

Kebidanan di Sulawesi Selatan Periode Juli - September Tahun 2020

\begin{tabular}{cccc}
\hline Tingkat Kecemasan & Kompeten & Tidak Kompeten & $\mathrm{p}$ \\
\hline Tinggi & 18 & 5 & 0,000 \\
Rendah & 40 & 129 & \\
\hline
\end{tabular}

Berdasarkan tabel 5. Dapat diketahui dengan hasil ujian kompetensi alumni bahwa secara statistik terdapat hubungan yang signifikan antara tingkat kecemasan

kebidanan di Sulawesi Selatan pada Periode Juli - September Tahun 2020.

Tabel 6. Hubungan Status Ujian Kompetensi dengan Hasil Ujian Kompetensi Pada Alumni Kebidanan di Sulawesi Selatan Periode Juli - Spetember Tahun 2020

\begin{tabular}{cccc}
\hline Frekuensi Keikutsertaan UKOM & Kompeten & Tidak Kompeten & $\mathrm{p}$ \\
\hline First Taker & 31 & 35 & 0,000 \\
Re Taker & 27 & 99 &
\end{tabular}

Berdasarkan tabel 6. Dapat diketahui bahwa secara statistic terdapat hubungan yang signifikan antara status ujian kompetensi dengan hasil ujian kompetensi alumni kebidanan di Sulawesi Selatan pada Periode Juli-September Tahun 2020.

\section{PEMBAHASAN}

\section{Hubungan Tingkat Kecemasan dengan Hasil Ukom}

Hasil penelitian menunjukkan bahwa terdapat hubungan yang signifikan antara tingkat kecemasan para lulusan kebidanan di Sulawesi Selatan kategori ukom (kompeten dan tidak kompeten) dengan. Hal ini sejalan dengan penelitian yang dilakukan oleh Yuliati dkk, tahun 2018 terkait hubungan hasil Supplementary Scales MMPI-2 terhadap hasil uji kompetensi pada alumni kebidanan Makassar periode Maret tahun 2018. (8)

Hal ini menunjukkan bahwa semakin besar tingkat kecemasan maka semakin mempengaruhi tingkat kelulusan uji kompetensi dan sebagian besar responden mengalami gejala kecemasan yang rendah. Berbeda dengan penelitian yang dikemukakan oleh Genting tahun 2018 yang menunjukkan tidak ada hubungan antara prestasi akademik dengan kecemasan alumni dalam menghadapi uji kompetensi Ners di STIKes Muhammadiyah Lamongan. (7)

Menurut Stuart dan Sundeen respon fisiologis individu terhadap kecemasan, yaitu: Kardiovaskuler: responnya berupa palpitasi, jantung berdebar, tekanan darah meningkat atau menurun, rasa mau pingsan, dan denyut nadi menurun. Pernafasan: responnya berupa nafas cepat dan dangkal, nafas pendek, tekanan pada dada, pembengkakan pada tenggorokan, sensasi tercekik, dan terengah-engah. Neuromuskuler: responnya berupa refleks meningkat, reaksi kejutan, mata berkedip - kedip, tremor, 
gelisah, wajah tegang, kelemahan umum, kaki goyang, dan gerakan yang janggal. Gastrointestinal: responnya berupa kehilangan nafsu makan, menolak makan, rasa tidak nyaman pada abdomen, mual, dan diare. Traktus urinarius : responnya berupa sering berkemih, tidak dapat menahan BAK. Kulit: responnya berupa wajah kemerahan, berkeringat setempat (telapak tangan), gatal, rasa panas dan dingin pada kulit, wajah pucat, dan berkeringat seluruh tubuh. (9)

Kecemasan yang timbul ketika menghadapi ujian menurut Mary RA, Rahim AFA, Baba AA, Ismail SB, Pa MNM, dan Esa AR tahun 2014 akan mempengaruhi performa mahasiswa yaitu mereka dengan tingkat kecemasan yang lebih rendah memberikan performa yang lebih baik dibanding mereka yang mengalami kecemasan sedang dan tinggi. (10)

\section{Hubungan Frekuensi Keikutsertaan Peserta dengan hasil ukom}

Hasil penelitian menunjukkan terdapat hubungan yang signifikan antara Frekuensi Keikutsertaan peserta dengan hasil uji kompetensi bidan. Hal ini sejalan dengan hasil analisis data Ayu Hartina tahun 2017 bahwa kategori frekuensi keikutsertaan UKNI first taker mendominasi responden yang lulus, yaitu 27 orang $(75 \%)$, sedangkan pada responden yang tidak lulus didominasi oleh retaker yaitu 19 orang $(52,8 \%)$.

Retaker memiliki peluang kecil untuk lulus uji kompetensi disebabkan oleh kurangnya persiapan menghadapi ukom baik kesiapan mental dan keilmuan. Persiapan mental mutlak diperlukan, apalagi lulusan yang pernah mengalami kegagalan di uji kompetensi sebelumnya.
Sedangkan kesiapan keilmuan adalah sikap lulusan pada saat proses belajar dan menerima materi pada saat menjadi mahasiswa. Hal ini sejalan dengan penelitian yang dilakukan Rohani Mustari tahun 2017 bahwa ada hubungan antara sikap dan kesiapan menghadapai uji kompetensi pada mahasiswa D III Kebidanan UIT makassar. (11,15)

Tekanan mental yang dihadapi mereka jauh lebih kuat dibanding dengan yang baru pertama kali mengikuti uji kompetensi. Mahasiswa retaker atau mahasiswa yang pada ujian pertama (first taker) belum kompeten, mereka mengalami kecemasan dan risiko untuk gagal lebih tinggi dibanding dengan first takers. Mahasiswa retakers sudah hanya memiliki kesempatan untuk kompeten sebesar 5 $16 \%$ dan secara nasional untuk first taker hanya kompeten sebanyak $40 \%$.

Pendapat ini sejalan dengan hasil penelitian Clareza Arie Werdhana pada tahun 2015 bahwa Responden pada penelitian ini pada umumnya baru sekali mengikuti UKMPPD (first taker), hanya didapatkan satu responden yang sudah mengikuti 10 UKMPPD sebelumnya (retaker) dan harus mengulang kembali. Pada responden yang first taker, sebagian besar mahasiswa mengalami kecemasan ringan $(59.1 \%)$. Sedangkan pada satusatunya responden yang retaker pada penelitian ini diketahui mengalami kecemasan sedang. Berdasarkan wawancara yang dilakukan oleh peneliti diketahui bahwa kecemasan yang timbul pada responden first taker karena merasa belum siap untuk menghadapi UKMPPD, sedangkan pada responden yang retaker karena responden takut mengulang 
kegagalan yang sudah pernah terjadi sebelumnya. (13)

SARAN

Setiap institusi pendidikan perlu mengukur tingkat kecemasan lulusan setiap menghadapi uji kompetensi dan pemberian intervensi kecemasan dengan pendekatan psikososial dan spritual, serta bimbingan belajar khusus untuk para retaker agar lebih siap menghadapi ujian kompetensi

Perlu penelitian lanjutan tentang perbandingan tingkat kecemasan pada first taker dan retaker dalam menghadapi Uji Kompetensi Bidan Indonesia.

\section{DAFTAR PUSTAKA}

1. Dirjen Dikti Kemedikbud. Standar Kompetensi Bidan ; 2011 https://fdokumen.com/document/184draft-standar-kompetensi-bidan-2011pdf.html, diakses tanggal 08 Desember 2020

2. Kemenkes. Survey Demografi dan Kesehatan Indonesia (SDKI). http://kesga.kemkes.go.id/images/pedoman/SDKI\%202012-Indonesia.pdf; 2012

3. Hayati, Rahmah Nur. Pengaruh Pengetahuan, Sikap Dan Motivasi Terhadap Minat Bidan Mengikuti Uji Kompetensi Di Kota Semarang Tahun 2007: http://eprints.undip.ac.id/18812/1/RAHMAH_NUR_HAYATI.pdf, diakses tanggal 08 Desember 2020

4. Benny Andreson Situmorang, Kristina L Silalahi. Pengaruh Focus Group Discussion Tentang Pelaksanaan Uji Kompetensi Terhadap Tingkatkecemasan Mahasiswa. Universitas Prima Indonesia; 2019

5. Ayu Hartina, Takdir Tahir, Nurhaya Nurdin , Midawati Djafar. Faktor Yang Berhubungan Dengan Kelulusan Uji Kompetensi Ners Indonesia (Ukni) Di Regional Sulawesi: http://jurnalppni.org/ojs/index.php/jppni/article/view/84/37, diakses tanggal 08 Desember 2020

6. Hadina et al. Faktor diri mahasiswa mempengaruhi kelulusan uji kompetensi D III Kebidanan di Poltekkes Kemenkes Palu. Politeknik Kesehatan Kementrian Kesehatan Palu: Jurnal Ilmu Kesehatan; Vol. 1 No 2 Mei 2017

7. Dadang Kusbiantoro . Hubungan Prestasi Akademik Dengan Kecemasan Alumni Dalam Menghadapi Uji Kompetensi Ners Di Stikes Muhammadiyah Lamongan. Prosiding Seminar Nasional 2018: http://jurnal.unmuhjember.ac.id/index.php/psn/article/view/1740/1427, diakses 09 Desember 2020

8. Yuliati, Saidah Syamsuddin, Budu. Hubungan Hasil Supplementary Scales Mmpi-2 Terhadap Hasil Uji Kompetensi Pada Alumni Kebidanan Makassar Periode Maret Tahun 2018, http://jurnal.umt.ac.id/index.php/jkft/article/view/2853, diakses 09 Desember 2020

9. Novi Anggraeni. Gambaran Tingkat Kecemasan Pada Mahasiswa Tingkat Tiga Prodi D3 Keperawatan Dalam Menghadapi Uji Kompetensi Di Universitas Pendidikan Indonesia : http://ejournal.upi.edu/index.php/JPKI; diakses 10 Desember 2020

10. Mary RA, Marslin G, Franklin G, Sheeeba CJ. Test Anxiety Level of Board Exam Going Student in Tamil Nadu, India. Hindawi Publishing Corporation. 2014

11. Anonim, http://tipdantrikukom.blogspot.com/2017/09/ , 2017

12. Dahlan M. Sopiyuddin. Statisitik. Jakarta: Epidemiologi Indonesia; 2017

13. Clareze Arief Werdhana, I Wayan Westa. Prevalensi Cemas Pada Mahasiswa Kedokteran Yang Mengikuti Uji Kompetensi Mahasiswa Program Profesi Dokter Di Fakultas Kedokteran Universitas Udayana. Program Studi Pendidikan Dokter Fakultas Kedokteran Universitas Udayana; 2015 
14. Kementerian Riset Teknologi dan Pendidikan Tinggi (Kemenristedikti). Data Statistis Tingkat Kelulusan Uji Kompetensi Bidan. 2018. Tersedia dari: http://ukbidan.ristekdikti.go.id/pages/statist ik_lulus ,diakses 11 Desember 2020

15. Mustari Rohani, Elis Andi. Faktor-Faktor Yang Mempengaruhi Pengetahuan Sikap Dan Motivasi Terhadap Ujian Kompotensi Pada Mahasiswa D-Iii Kebidanan UIT Makassar. Makassar: Fakultas Keperawatan Universitas Indonesia Timur;2017. 